\title{
An Overview of Peptide-Based Molecules as Potential Drug Candidates for Multiple Sclerosis
}

\author{
Annarita Del Gatto ${ }^{1,2, *(\mathbb{D})}$, Michele Saviano ${ }^{2,3}$ (D) and Laura Zaccaro ${ }^{1,2, *(\mathbb{D})}$ \\ 1 Institute of Biostructures and Bioimaging, CNR, 80134 Naples, Italy \\ 2 CIRPeB, University of Naples "Federico II", 80134 Naples, Italy; msaviano@unina.it \\ 3 Institute of Crystallography, CNR, 70126 Bari, Italy \\ * Correspondence: annarita.delgatto@unina.it (A.D.G.); lzaccaro@unina.it (L.Z.)
}

check for updates

Citation: Del Gatto, A.; Saviano, M.; Zaccaro, L. An Overview of PeptideBased Molecules as Potential Drug Candidates for Multiple Sclerosis. Molecules 2021, 26, 5227. https:// doi.org/10.3390/molecules26175227

Academic Editor:

Aleksandra Misicka-Kesik

Received: 5 July 2021

Accepted: 4 August 2021

Published: 28 August 2021

Publisher's Note: MDPI stays neutral with regard to jurisdictional claims in published maps and institutional affiliations.

Copyright: (c) 2021 by the authors. Licensee MDPI, Basel, Switzerland. This article is an open access article distributed under the terms and conditions of the Creative Commons Attribution (CC BY) license (https:// creativecommons.org/licenses/by/ $4.0 /)$.

\begin{abstract}
Multiple sclerosis (MS) belongs to demyelinating diseases, which are progressive and highly debilitating pathologies that imply a high burden both on individual patients and on society. Currently, several treatment strategies differ in the route of administration, adverse events, and possible risks. Side effects associated with multiple sclerosis medications range from mild symptoms, such as flu-like or irritation at the injection site, to serious ones, such as progressive multifocal leukoencephalopathy and other life-threatening events. Moreover, the agents so far available have proved incapable of fully preventing disease progression, mostly during the phases that consist of continuous, accumulating disability. Thus, new treatment strategies, able to halt or even reverse disease progression and specific for targeting solely the pathways that contribute to the disease pathogenesis, are highly desirable. Here, we provide an overview of the recent literature about peptide-based systems tested on experimental autoimmune encephalitis (EAE) models. Since peptides are considered a unique therapeutic niche and important elements in the pharmaceutical landscape, they could open up new therapeutic opportunities for the treatment of MS.
\end{abstract}

Keywords: demyelinating diseases; multiple sclerosis; peptides; therapy; EAE

\section{Introduction}

Multiple sclerosis (MS) is a chronic inflammatory disease of the central nervous system (CNS) that leads to progressive neurodegeneration. A crux of the disease is an autoimmune attack of the self-antigens, that is the proteins of the myelin sheath that wrap around the nerve fibers are mistaken for foreign agents by macrophages, $\mathrm{CD} 4^{+} \mathrm{T}, \mathrm{CD} 8^{+} \mathrm{T}$, and $\mathrm{B}$ cells infiltrating the blood-brain barrier (BBB). The role of the myelin sheath is crucial both to provide protection and nourishment to nerve fibers and to enable the efficient transmission of nerve impulses. Demyelination elicits axonal injury, plaques, or lesions' formation in the brain and spinal cord, and causes a range of symptoms, depending on the neurons that are affected [1-5]. MS is a very heterogeneous disease, with different pathological and clinical manifestations. It is estimated that worldwide, more than 2.3 million people between ages 20 to 50 are affected by MS, that is usually diagnosed with signs and symptoms that may differ from person to person and throughout the disease, such as loss of balance and coordination, visual and sensory deficiency, fatigue, weakness, vertigo, pain, and cognitive difficulties [6]. Before being officially diagnosed with MS, patients can experience a first neurologic event indicative of potential MS, defined as Clinically Isolated Syndrome, that lasts for at least $24 \mathrm{~h}$ with symptoms and signs indicating either a single lesion (monofocal) or more than one lesion (multifocal) within the CNS. Multiple sclerosis is divided into four types, named according to the way the disease acts on the body over time: Progressive Relapsing MS (PRMS), characterized by a steady degeneration since onset with super-imposed attacks, Relapsing-Remitting MS (RRMS), the most common disease course diagnosed for $85 \%$ of people, characterized by defined attacks of new or even increasing neurological symptoms (relapses), followed by periods of partial or complete 
recovery (remissions), Primary Progressive MS (PPMS), consisting of progressive disability from the onset of symptoms, and Secondary Progressive MS (SPMS), marked by an initial relapsing-remitting course that suddenly begins to progressively decline over time $[7,8]$.

\subsection{Immunopathogenesis of $M S$}

The pathogenesis of MS is still unknown: immune-system cells and proteins that can have a crucial role in the initiation and progression of disease are not fully understood. A multitude of factors may cause the insurgence of this disease, ranging from genetic factors, such as class-II allele of the major histocompatibility complex (MHC) [9,10], to environmental agents, such as pathogenic infections [11,12]. Some correlations actually have been made between MS and different viruses, such as varicella zoster [13] and the Epstein-Barr virus [14,15], or bacteria such as chlamydia pneumonia [16-18], as well as other environmental factors such as vitamin D deficiency, smoking, and obesity [8]. Despite this, direct evidence of a correlation between pathogenic infections and MS is still lacking, with the most commonly accepted hypothesis being that MS is an autoimmune disease affecting genetically predisposed individuals already plagued by an environmental pathogen [19].

An intricate interplay of inflammatory cells (T cells, B cells, and macrophages) and CNS resident cells (microglia, astrocytes, oligodendrocytes, and neurons) is associated with the pathology. Among the different cells of the innate and adaptive immune systems that may arrange the inflammatory response within the CNS, a key role is played by autoreactive $\mathrm{CD}^{+} \mathrm{T}$ cells that migrate into the CNS [20-24] after the activation in the peripheral lymph nodes. Many findings indicate a central role of Th1, Th17, Th1-Th17-like, Th22, and Granulocyte-Macrophage Colony-Stimulating Factor (GM-CSF)-producing CD4 ${ }^{+} \mathrm{T}$ cells, in beginning and prolonging the inflammatory reactions and in causing neurodegeneration in MS as well as dysfunction in regulatory $T$ cell $\left(\mathrm{T}_{\text {reg }}\right)$ subsets $[25,26]$. In the CNS, these cells are reactivated and secrete cytokines and chemokines, thus contributing to the breakdown of the $\mathrm{BBB}$, the activation of resident astrocytes and microglia, and finally, the mediation of inflammatory reaction responsible for the distinctive lesions of the disease [27].

\subsection{Current Available Therapeutic Approaches}

At present, there is no definite cure for MS, but therapies based on immunosuppressive and immune-modulating agents can modify or slow the course of disease and manage symptoms. Several disease-modifying treatments (DMTs) to treat relapsing forms of MS have been developed and proved able to reduce the frequency and severity of relapses as well as the accumulation of lesions in the CNS. They cover injectable and orally administrated drugs, monoclonal antibodies, transplantation of autologous bone marrow, strategies to restore myelination, and targeting T cells, besides mesenchymal stem cells' employment. So far, about 20 DMTs, approved by the FDA, are available in many countries for the different types of MS (www.nationalmssociety.org/For-Professionals/ClinicalCare/Managing-MS/Disease-Modification, accessed on 3 August 2021), but they can only minimize symptoms, preserving patients as relapse-free, with no new lesion visible on MRI. Moreover, the most current therapies are not specific but suppress the general immune response, leading to many negative side effects. For this, the development of therapeutic agents able to specifically control and modulate the immune response is an urgent need.

In this context, peptide molecules appear as appealing candidates for many reasons [28]. In fact, some of them have a deep impact on important physiological mechanisms controlling many vital functions in humans, such as metabolism, respiration, reproduction, and immune defense. They possess many advantages over other classes of molecules, being small in size (up to 50 amino acids), easy to synthesize, and having the ability to penetrate the cell membranes, mainly when bearing specific modifications (N-methylation, stapling, etc.). They also have high activity, specificity, and affinity, good efficacy and tolerability, as well as biological and chemical diversity. As a result, an increasing number of peptides are both entering clinical trials and being approved as drugs. 
In this review, attention is pointed to some peptides reported in the recent literature representing new potential candidates for MS therapy. Generally, for pre-clinical studies, the experimental autoimmune encephalitis is the most commonly used immune-driven demyelinating model that closely resembles RRMS. It is an animal model of brain inflammation induced by immunization with neural antigens, such as myelin oligodendrocyte glycoprotein (MOG) or proteolipid protein (PLP). Additionally, the cuprizone model, that mimics the acute and chronic courses of MS and is thus suited for the study of the demyelination mechanism, represents a valid tool to develop novel therapies aimed at protecting oligodendrocytes and promoting remyelination.

Here, we describe peptide systems arbitrarily sorted into two groups: peptides modulating T cells' functions and peptides modulating cells other than T lymphocytes (Figure 1).

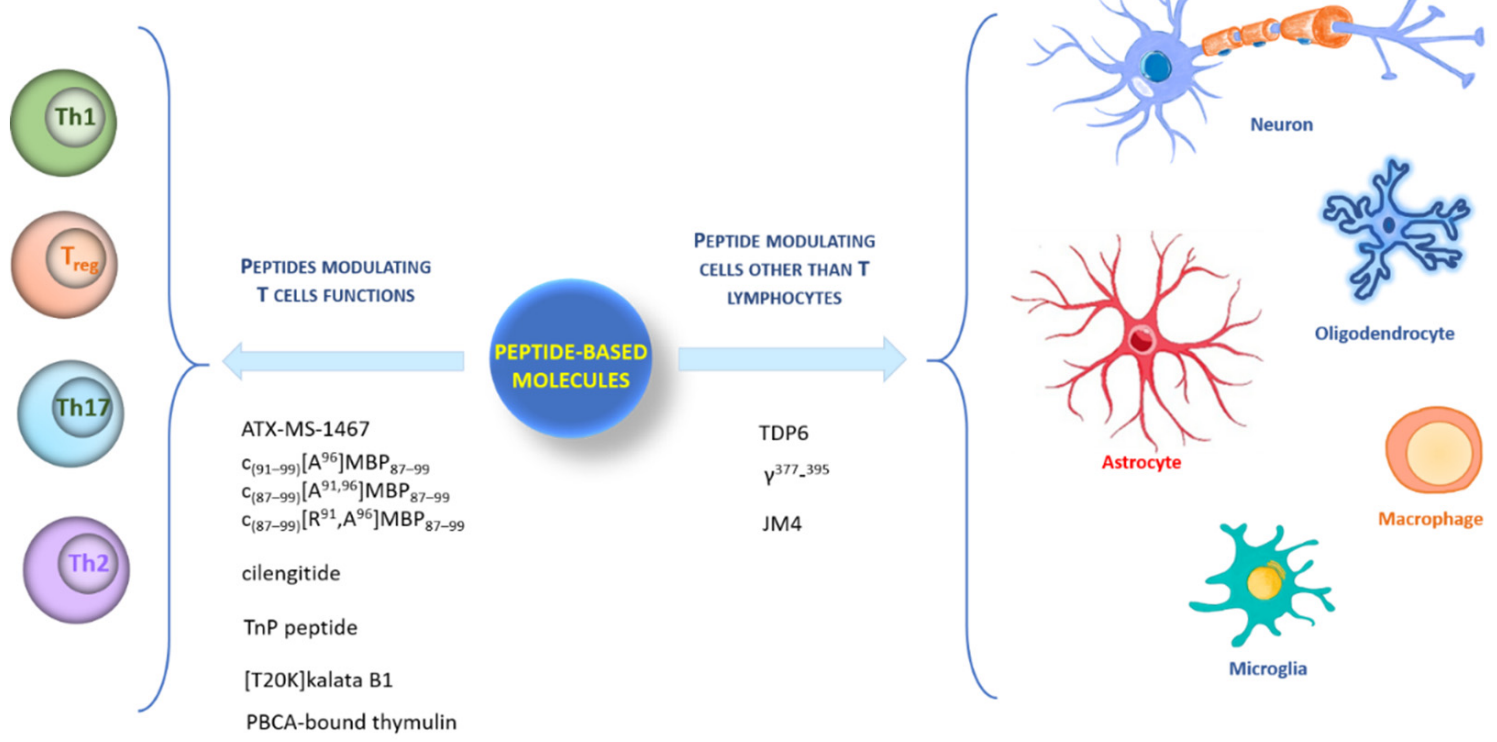

Figure 1. Graphic representation of different type of cells targeted by peptides.

\section{Peptides Modulating T Cells' Functions}

Currently, MS therapies are unable to specifically regulate immune cells because they suppress the overall immune system, causing undesirable side effects from opportunistic infections. Thus, to preserve host capability provided by the general immune response to protect against extraneous pathogens, the development of therapeutic agents capable of specifically controlling the myelin-reactive immune response is required.

\subsection{Myelin-Based Autoantigen Peptides: ATX-MS-1467, $c_{(91-99)}\left[A^{96}\right] M B P_{87-99}$, $c_{(87-99)}\left[A^{91,96}\right] M B P_{87-99}$, and $c_{(87-99)}\left[R^{91}, A^{96}\right] M B P_{87-99}$}

Antigen-specific treatments targeting key regulators in the failure of tolerance to self-antigens, such as myelin basic protein (MBP), were developed to silence or reprogram autoreactive $\mathrm{T}$ cells in the peripheral zone to a regulatory phenotype, thus creating a tolerogenic state to the targeted protein $[29,30]$. Autoantigen T-cell responses to MBP are known to be involved in the pathogenesis of MS [31-34], and, in particular, five of the eight identified regions of MBP are the most recognized by T-cells. Based on this consideration, Streeter and coworkers in 2015 [35] reported for the first time a study on ATX-MS-1467, a cocktail of four peptides derived from the MBP region (MBP 30-44 [ATX-MS1], MBP 130-144 [ATX-MS4], 140-154 [ATX-MS6], and MBP 83-99 [ATX-MS7], Table 1), which resulted acting as apitopes (antigen processing independent epitope) and to prevent the worsening of signs of disease in EAE in a humanized mouse, (DR2 9 Ob1)F1, in a dosedependent fashion. A few years later, De Souza et al. [36] demonstrated that subcutaneous 
treatment with an ATX-MS-1467 mixture, after established induction of EAE in the same mouse model, was able to reverse the clinical disability, to diminish the histological markers of inflammation and demyelination, and to reduce the T-cell and B-cell infiltration in the spinal cord and the disruption of BBB integrity, as shown in MRI analysis. All these effects were more evident in the animals treated early in the progression of EAE rather than later, thus demonstrating the neuroprotective benefit of the ATX-MS-1467 mixture when early administration was carried out. Furthermore, De Souza et al. speculated that chronic treatment with ATX-MS-1467 induced a shift from a pro-inflammatory to a tolerogenic state in the periphery, as revealed by the increase in IL-10 secretion relative to cytokine IL-2, IL-17, and IFN-c, and by the induction of splenic-induced $\mathrm{T}_{\text {regs }}$ as resulting from a decrease in splenocyte proliferation and the increase in IL- $10^{+}$Foxp $^{-}$T regulatory cell sub-populations in the spleen. ATX-MS-1467 is in clinical Phase II in patients with RRMS to evaluate the clinical, biological, and radiological effects and the safety profile (https: / / www.mstrust.org.uk/a-z/atx-ms-1467, accessed on 3 August 2021).

Different cyclic peptides derived from $\mathrm{MBP}_{87-99}$ epitope [37-42], another candidate autoantigen in MS, were also explored for therapeutic efficacy in EAE. Previous studies $[43,44]$ evidenced the importance of Lys91 and Pro96 of MBP $_{87-99}$ in anchoring T-cell receptor (TCR) and in the involvement in the trimolecular complex between the TCRntigen (peptide)-MHC for the activation of encephalitogenic T cells necessary for EAE induction (Table 1). In fact, the replacement of these two residues with Arg and/or Ala, respectively, induced protective effects against EAE in mice. The peptide analogues cyclo

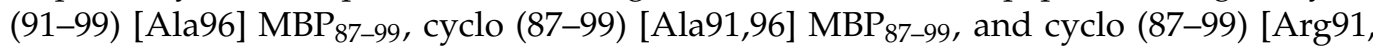
Ala96] $\mathrm{MBP}_{87-99}$ (Table 1) were administered in $\mathrm{MBP}_{72-85}$-induced EAE in Lewis rats using prophylactic and early therapeutic vaccination protocols [45]. These peptides, but not wild-type linear $\mathrm{MBP}_{87-99}$, strongly inhibited EAE, and in particular, cyclo (87-99) [Arg91, Ala96] $\mathrm{MBP}_{87-99}$ was highly active in preventing the onset and development of clinical symptoms and pathologies correlated with the spinal cord, providing long-term protection against EAE induction through an active mechanism.

\subsection{Peptides Modulating Th Cell Subsets: Cilengitide, TnP Peptide, [T20K] Kalata B1, Thymulin}

It is widely documented that integrins are transmembrane receptors promoting the migration of cells into inflamed tissues by interactions with inflamed endothelium and stromal extracellular matrix constituents. Hence, molecules able to interfere with, or even to block, integrin activity can be employed as therapeutics in the treatments of MS. An example is the monoclonal antibody Natalizumab, approved by the FDA for the treatment of RRMS, which acts as an $\alpha 4$ integrin antagonist to prevent migration of inflammatory $\mathrm{T}$ cells into the CNS. The antibody proved highly effective in some patients, even if its administration is associated with the risk of progressive multifocal leukoencephalopathy. Lately, it has been reported that a 4 integrin is definitively not essential for cell access of Th17 to the CNS. Recent data pointed out the key role of interleukin 23 (IL-23) in triggering the pathogenic features in pro-inflammatory Th17 in EAE by inducing Th17 cell proliferation, and particularly the switch to effector phenotype after the initial signals for differentiation induced by transforming $\beta$ growth factor, IL-6, and IL-1 [46-49]. As evidence of this, mice lacking in IL-23 or IL-23R were highly resistant to Th17-mediated autoimmune inflammation. In the last years, different groups independently stated an increased integrin $\beta 3$ expression in Th17-associated diseases, such as psoriasis, psoriatic arthritis, rheumatoid arthritis, and MS [50-53]. In addition, this integrin is known to bind ECM proteins, such as osteopontin, tightly associated with autoimmune diseases [54], and vitronectin and fibronectin, for which increased levels of expression in the CNS in both EAE and MS have been found [55,56]. In 2016, Du and collaborators reported for the first time [57] a deep study on the expression and function of $\alpha v \beta 3$ integrin on Th17 cells in the context of autoimmune disease in EAE model and elucidated its interesting connections with the IL-23/Th17 axis. Notably, an increased integrin $\alpha \mathrm{v} \beta 3$ expression in an IL-23-dependent manner was observed only on Th17 lineage, that expanded during the progression of EAE, 
but not on all activated $\mathrm{T}$ cells or Th1 cells. These findings supported a further role of the integrin in promoting migration of inflammatory T cells into the CNS parenchyma to start inflammation. By confirming these data, the cilengitide (Table 1), an $\alpha \mathrm{v} \beta 3 / \alpha \mathrm{v} \beta 5$ antagonist, was administered from day 4 after animal immunization with MOG (35-55) and a significant reduction of EAE severity over untreated mice was observed. These results indicate a crucial targetable function for integrin $\alpha v \beta 3$ expression by inflammatory Th17 cells and pave the way for testing further selective $\alpha \mathrm{v} \beta 3$ antagonists [58,59] in the EAE model as a different perspective in the MS scenario.

Komegae et al. [60] identified new peptide molecules, denominated the TnP family, derived from the venom of Thalassophryne nattereri Brazilian fish, which was utilized for drug discovery and development. The TnP family, subjected to a patent application in several countries all over the world, comprises synthetic peptides with anti-inflammatory and antiallergic activities. In particular, the authors focused on a specific TnP peptide (Table 1) and employed the myelin-dependent EAE model [61] to evaluate its anti-inflammatory effect and therapeutic potential in MS. Moreover, they used the toxic model of cuprizone $[62,63]$ to also assess its potential to induce remyelination. They reported very interesting results: treatment with TnP peptide enhanced EAE in an IL-10-dependent manner, prompting reduction of disease severity and the beginning of symptoms. A controlled infiltration of leukocytes in CNS, demyelination inhibition, decrease in the expansion of microglia and of the activity of MMP-9 by F4 $/ 80^{+}$macrophages were also evidenced. TnP proved able to modulate the encephalitogenic $\mathrm{CD}^{+} \mathrm{T}$ cells, reducing the infiltration of IFN- $\gamma$-producing Th1 and IL-17A-producing Th17 cells in the CNS, to block inflammatory cytokines' production in the spleen, and to promote the presence of functional Treg in the spleen and the CNS. Finally, the TnP peptide showed the ability to accelerate remyelination in the cuprizone model, proving to be a very active and interesting anti-inflammatory and proremyelinating molecule to use as a lead compound to design new drugs for demyelinating conditions typical of MS.

Many drugs for MS treatment are unfortunately administered by the parenteral route, and innovative orally active therapeutics are desirable, mainly for the treatment of chronic forms. [T20K] kalata B1 (Table 1) is a plant-derived peptide belonging to the family of cyclotides, well-known for their cyclic fold stabilized by a cystine knot motif of three disulfide bonds resistant to chemical, enzymatic, and thermal degradation [64]. As a result, cyclotides are very attractive weapons in drug discovery and development because they may be administered by the oral route.

An in vitro effect of [T20K] kalata B1 in inhibiting T-cell proliferation through the decrease of the expression of the IL-2 surface receptor as well as IL-2 cytokine secretion and IL-2 gene expression was reported [65]. This is extremely relevant considering the physiological role of IL-2 in T-lymphocyte activation and its action as an autocrine factor for stimulating T-cell proliferation, with consequent loss of immune tolerance. Recently, Thell and coworkers thoroughly described the ability of the peptide to reduce IL-2 and IFN- $\gamma$ secretion as well as to significantly lower the degree of demyelination and inflammation in EAE mice after oral treatment [66]. Notably, a considerable decrease in T-cell cytokine IL-17A, supporting the observed clinical and histological reversion of disease evolution upon peptide treatment, was also evidenced. Remarkably, this study for the first time evidences the use of cyclotides as potential oral active therapeutics for EAE.

$\mathrm{NF}-\mathrm{KB}$ is one of the most important transcription factors, whose activation in inflammatory cells, including $\mathrm{T}$ cells, and some resident cells such as microglia/macrophages and astrocytes, increases inflammation and promotes the development of MS and EAE [67]. There is also abundant evidence that the NF- $\mathrm{KB}$ pathway is crucial for maintaining immunological tolerance as it participates in the negative selection of autoreactive $\mathrm{T}$ cells and the selection and maintenance of Treg cells. Lunin et al. [68] showed that the induction and maintenance of acute EAE forms were associated with NF- $\mathrm{kB}$ pathway activation, and NF- $\mathrm{kB}$ signaling inhibition alleviated acute EAE symptoms. The regulation of the NF-kB pathway in EAE is attained by site-specific phosphorylation of a RelA/p65 protein 
from the NF-kB family [68]. An increased RelA/p65 (Ser276) phosphorylation, commonly attributed to PKA, corresponded with the production of IF- $\gamma$, Hsp72, and the initial phase of IL-17 production associated with the early phase of the disease, whereas increased RelA/p65 (Ser536) phosphorylation was correlated not only with the activation of IKK, SAPK/JNK, and p53, but also with the late phase of IL-17 secretion and the pathology progression. Lunin and coworkers $[69,70]$ experienced that the thymic peptide thymulin, a metallopeptide consisting of a nonapeptide (Table 1) in complex with a zinc ion, in addition to producing effects on the neuroendocrine stress response system [69-71], shows analgesic activity in inflammatory conditions [72] and in severe and mild progressive forms of EAE [73,74]. Recently [75], the thymulin was bound to polybutylcyanoacrylate (PBCA) nanoparticles for enhancing the bioavailability of the free peptide [76], and the properties of both forms of the peptide were also evaluated on relapse and remitting EAE. It was demonstrated that the ability to reduce the phosphorylation at Ser536 was the same for thymulin and PBCA-bound thymulin, while a deeper effect on phosphorylation at Ser276 was observed in animals treated with peptide-conjugate with respect to free peptide. From this evidence, the PBCA-bound thymulin was also found to be more active in reducing overall symptoms of the disease in comparison with free thymulin.

\section{Peptides Modulating Other Cells besides T Lymphocytes}

Since there is such a large number of MS immunomodulatory therapies with different modes of action already available, many experts believe that the research aiming to develop truly novel immune therapies is unsuccessful. Despite this huge choice of treatments, none are capable of fully silencing the pathology and failures occur with all the accessible drugs. Thus, MS treatment needs to advance with the development of neuroprotective and regenerative therapies aiming to complement existing immunomodulatory therapies [77].

\subsection{Remyelination-Enhancing Peptide: TDP6}

For remyelination, it is necessary to have a presence of functionally undamaged axons and oligodendroglial progenitor cells (OPCs) that can differentiate, form contact with and ensheath axons, as well as generate compact myelin [77]. Brain-derived neurotrophic factor (BDNF, Table 1) plays extremely important roles in CNS myelination, acting by oligodendrocyte-expressed TrkB receptors. BDNF exerted an effect in increasing myelin sheath thickness, but the failure of the clinical trials in neurodegenerative diseases was due to its promiscuity to interact with both $\mathrm{p} 75^{\mathrm{NTR}}$ and TrkB receptors, and therefore its short half-life, large molecular size, and low capability to cross the BBB [78]. A recent paper by Fletcher et al. [78] reported the tricyclic-dimeric-peptide-6 (TDP6, Table 1), a BDNF mimetic, that selectively interacts with the oligodendroglial TrKB receptor and not with the $\mathrm{p} 75^{\mathrm{NTR}}$ one. The peptide enhances remyelination, increases oligodendrocyte differentiation, the frequency of myelinated axons, and the myelin sheath thickness following a demyelinating insult. All these outcomes support the modulation of TrkB signaling as an effective therapeutic strategy to further myelin repair.

\subsection{Peptide Inhibiting Microglia Activation: $\gamma^{377-395}$}

Significant data indicate that in MS lesions, a co-localization of perivascular activated microglia with areas of BBB breakdown occurs [79]. One of the main events correlated with the BBB disruption is the escape of blood protein fibrinogen in the CNS and relative perivascular deposition of fibrin that interacts with the Mac-1 microglia receptor. This action induces local activation of microglia and increases its capability to phagocytose myelin and secrete pro-inflammatory cytokines. Adams and colleagues reported that the fibrinogen-derived peptide $\gamma^{377-395}$ (Table 1) can directly block fibrinogen-Mac1-dependent microglial activation both in vitro and in vivo without effects on coagulation [80]. Specifically, the peptide attenuates the clinical symptoms in EAE by mainly reducing the microglia/macrophage response without affecting $\mathrm{T}$ cell activation. Accordingly, the inhibition of fibrin-Mac-1 interactions could be helpful as a microglia-suppressive 
therapy in MS and could be employed in association with other therapies targeting diverse systems involved in the onset of the disease.

\subsection{Peptide Regulating T Cell Subsets and CNS Resident Cells: JM4}

Beneficial immunomodulatory and anti-inflammatory effects of Erythropoietin (Epo) have been demonstrated in the MOG-Induced Monophasic EAE model [81]. Unfortunately, these features are associated with excessive hematopoiesis that prevents Epo application in the therapeutic field [82-84]. In 2015, Yuan's group designed a peptide derived from Epo protein, named JM4 (Table 1), which shares the valuable properties of whole molecule Epo in EAE mice, but not its side effects [85-87]. The authors demonstrated that both Epo and JM4 act by reducing raised mononuclear cell counts to normal, dendritic cells by ten-fold, and proinflammatory cytokines such as IL-2, IL-6, TNF-alpha, and INF-gamma. Moreover, JM4 peptide can normalize the damaged BBB, downregulate the MHC class II expression, enhance the expansion of the Treg-cell population, and reduce $\mathrm{T}$ helper Th17-positive cells in SJL/J relapsing-remitting EAE mice [85]. Notably, the peptide also sustains the neuroprotective A2 astrocytes over the cytotoxic A1 astrocytes, the latter of which are upregulated in MS, where they trigger the death of oligodendrocytes and neurons [88]. Additionally, since microglial activation is noted to induce A1 reactive astrocytosis, JM4 may act by suppressing the M1 macrophages or microglia development. Importantly, the long-term therapeutic benefit with no side effects observed with a short-term JM4 treatment in EAE mice [89] looks like that recently described in patients treated with the pulsed immune reconstitution therapy, alemtuzumab and cladribine, that are the new FDA-approved drugs for MS therapy [90].

Table 1. Peptide sequences.

\begin{tabular}{|c|c|c|}
\hline Name & Sequence & Ref \\
\hline ATX-MS-1467 & $\begin{array}{l}\text { ATX-MS1: PRHRDTGILDSIGRF } \\
\text { [ATX-MS4]: GFKGVDAQGTLSKIF } \\
\text { [ATX-MS6]: GFKGVDAQGTLSKIF } \\
\text { [ATX-MS7]: ENPVVHFKNIVTPRTP }\end{array}$ & [34] \\
\hline cyclo (91-99) [Ala $\left.{ }^{96}\right] \mathrm{MBP}_{87-99}$ & VHFFKNIVTARTP & [44] \\
\hline cyclo (87-99) $\left[\mathrm{Ala}^{91,96}\right] \mathrm{MBP}_{87-99}$ & \begin{tabular}{l|} 
VHFFANIVTARTP \\
\end{tabular} & \\
\hline cyclo (87-99) $\left[\mathrm{Arg}^{91}{ }^{91} \mathrm{Ala}^{96}\right] \mathrm{MBP}_{87-99}$ & $\begin{array}{l} \\
\text { VHFFRNIVTARTP }\end{array}$ & \\
\hline Cilengitide & $\mathrm{c}(\mathrm{RGDf}(\mathrm{NMe}) \mathrm{V})$ & [56] \\
\hline TnP peptide & IPRCRKMPGVKMC-NH & [59] \\
\hline [T20K]kalata B1 & $\overbrace{\text { GLPVCGETCVGGTCNTPGCKCSWPVCTRN }}^{\mp}$ & [65] \\
\hline Thymulin & EAKSQGGSD & {$[74,75]$} \\
\hline TDP6 & $\begin{array}{l}\text { Ac-CVPVCKGQLCE-NH} H_{2} \\
\text { Ac-CVPVCKGQLCK-NH } \mathrm{N}_{2} \\
\square\end{array}$ & [77] \\
\hline $\begin{array}{c}\gamma 377-395 \\
\text { JM4 }\end{array}$ & $\begin{array}{l}\text { YSMKKTTMKIIPFNRLTIG } \\
\text { GCAEHCSLNENITVPDTKV }\end{array}$ & $\begin{array}{l}{[79]} \\
{[88]}\end{array}$ \\
\hline
\end{tabular}

\section{Conclusions}

Multiple sclerosis is a serious neuroinflammatory disease with disseminated focal lesions affecting myelin and neuronal loss in the CNS, clinically characterized by unpre- 
dictable course and increasing disability. To date, 22 DMTs approved by the FDA are available in the clinic for the different types of MS. Unfortunately, the efficacy, tolerability, and safety profile of these drugs vary widely, ranging from modest activity with remarkable safety to highly effective activity with increased risk of serious adverse events also associated with the unspecific mechanisms of action. Consequently, the discovery of new therapeutic agents acting by specific control and modulation of the immune response is a great challenge.

Over the last decades, the use of peptides as drugs has advanced and continues to grow with changes in drug development and treatment protocols.

An illustrative but not exhaustive list of different peptides as potential candidates in MS therapy has been reported here. The use of these molecules offers numerous advantages, even if in some cases the low solubility and enzymatic stability or the suboptimal pharmacokinetic properties may limit their employment. These drawbacks could be overcome by introducing chemical modifications in peptide backbone, or directly conjugating these peptides with adequate vehicles (peptides, liposomes, nanoparticles) to improve targeted delivery also through the $\mathrm{BBB}$, and/or therapeutic activity. In addition, the preparation of dendrimers made up of multiple copies of the same or different peptides in a unique molecule provides branched systems with synergistic effects and almost unlimited potential in biomedicine.

In conclusion, the interesting results and the perspectives reported here open a new scenario for drug innovation in the MS field.

Author Contributions: Conceptualization, Data Curation, Writing-Original Draft, Writing—Review and Editing, Project Administration, A.D.G.; Supervision, Funding Acquisition, M.S.; Data Curation, Writing-Original Draft, Writing—Review and Editing, Project Administration, L.Z. All authors have read and agreed to the published version of the manuscript.

Funding: This research received no external funding.

Institutional Review Board Statement: Not applicable.

Informed Consent Statement: Not applicable.

Data Availability Statement: Not applicable.

Acknowledgments: We are grateful to Maurizio Amendola (Institute of Biostructures and Bioimaging, CNR, Naples) for technical assistance, and Luca De Luca (Institute of Biostructures and Bioimaging, CNR, Naples) for computer assistance.

Conflicts of Interest: The authors declare that they have no known competing financial interests or personal relationships that could have appeared to influence the work reported in this paper.

\section{References}

1. Ransohoff, R.M. Immune-cell crosstalk in multiple sclerosis. Nature 2018, 563, 194-195. [CrossRef] [PubMed]

2. Willekens, B.; Cools, N. Beyond the Magic Bullet: Current Progress of Therapeutic Vaccination in Multiple Sclerosis. CNS Drugs 2018, 32, 401-410. [CrossRef]

3. Dendrou, C.A.; Fugger, L.; Friese, M.A. Immunopathology of multiple sclerosis. Nat. Rev. Immunol. 2015, 15, 545-558. [CrossRef]

4. Grigoriadis, N.; van Pesch, V. A basic overview of multiple sclerosis immunopathology. Eur. J. neurol. 2015, 22, 3-13. [CrossRef] [PubMed]

5. Nuyts, A.H.; Lee, W.P.; Bashir-Dar, R.; Berneman, Z.N.; Cools, N. Dendritic cells in multiple sclerosis: Key players in the immunopathogenesis, key players for new cellular immunotherapies? Mult. Scler. 2013, 19, 995-1002. [CrossRef]

6. McFarland, H.F.; Martin, R. Multiple sclerosis: A complicated picture of autoimmunity. Nat. Immunol. 2007, 8, 913-919. [CrossRef] [PubMed]

7. Baldassari, L.E.; Feng, J.; Clayton, B.L.L.; Oh, S.H.; Sakaie, K.; Tesar, P.J.; Wang, Y.; Cohen, J.A. Developing therapeutic strategies to promote myelin repair in multiple sclerosis. Expert Rev. Neurother. 2019, 19, 997-1013. [CrossRef]

8. Gholamzad, M.; Ebtekar, M.; Ardestani, M.S.; Azimi, M.; Mahmodi, Z.; Mousavi, M.J.; Aslani, S. A comprehensive review on the treatment approaches of multiple sclerosis: Currently and in the future. Inflamm. Res. 2019, 68, 25-38. [CrossRef]

9. Compston, A. The genetic epidemiology of multiple sclerosis. Philos. Trans. R. Soc. Lond. B. Biol. Sci. 1999, 354, 1623-1634. [CrossRef] 
10. Lincoln, M.R.; Montpetit, A.; Cader, M.Z.; Saarela, J.; Dyment, D.A.; Tiislar, M.; Ferretti, V.; Tienari, P.J.; Sadovnick, A.D.; Peltonen, L.; et al. Hudson, A predominant role for the HLA class II region in the association of the MHC region with multiple sclerosis. Nat. Genet. 2005, 37, 1108-1112. [CrossRef] [PubMed]

11. Sospedra, M.; Martin, R. Immunology of multiple sclerosis. Annu. Rev. Immunol. 2005, 23, 683-747. [CrossRef] [PubMed]

12. Fujinami, R.S.; von Herrath, M.G.; Christen, U.; Whitton, J.L. Molecular mimicry, bystander activation, or viral persistence: Infections and autoimmune disease. Clin. Microbiol. Rev. 2006, 19, 80-94. [CrossRef] [PubMed]

13. Gilden, D.H. Infectious causes of multiple sclerosis. Lancet. Neurol. 2005, 4, 195-202. [CrossRef]

14. Pender, M.P. Does Epstein-Barr virus infection in the brain drive the development of multiple sclerosis? Brain 2009, 132, 3196-3198. [CrossRef] [PubMed]

15. Bagert, B.A. Epstein-Barr virus in multiple sclerosis. Curr. Neurol. Neurosci. Rep. 2009, 9, 405-410. [CrossRef]

16. Gaydos, C.A. Chlamydia pneumoniae and its proposed link to multiple sclerosis: To be or not to be? Neurology 2001, 56, 1126-1127. [CrossRef]

17. Jacobson, S.; Cross, A. Association of Chlamydia pneumoniae and multiple sclerosis: Stage two? Neurology 2001, 56, 1128-1129. [CrossRef]

18. Yao, S.Y.; Ljunggren-Rose, A.; Stratton, C.W.; Mitchell, W.M.; Sriram, S. Regulation by IFN-beta of inducible nitric oxide synthase and interleukin-12/p40 in murine macrophages cultured in the presence of Chlamydia pneumoniae antigens. J. Interferon. Cytokine Res. 2001, 21, 137-146. [CrossRef] [PubMed]

19. Kenealy, S.J.; Pericak-Vance, M.A.; Haines, J.L. The genetic epidemiology of multiple sclerosis. J. Neuroimmunol. 2003, 143, 7-12. [CrossRef]

20. Hafler, D.A.; Benjamin, D.S.; Burks, J.; Weiner, H.L. Myelin basic protein and proteolipid protein reactivity of brain- and cerebrospinal fluid-derived T cell clones in multiple sclerosis and postinfectious encephalomyelitis. J. Immunol. 1987, 139, 68-72.

21. Ota, K.; Matsui, M.; Milford, E.L.; Mackin, G.A.; Weiner, H.L.; Hafler, D.A. T-cell recognition of an immunodominant myelin basic protein epitope in multiple sclerosis. Nature 1990, 346, 183-187. [CrossRef] [PubMed]

22. Zamvil, S.; Nelson, P.; Trotter, J.; Mitchell, D.; Knobler, R.; Fritz, R.; Steinman, L. T-cell clones specific for myelin basic protein induce chronic relapsing paralysis and demyelination. Nature 1985, 317, 355-358. [CrossRef]

23. Zamvil, S.S.; Nelson, P.A.; Mitchell, D.J.; Knobler, R.L.; Fritz, R.B.; Steinman, L. Encephalitogenic T cell clones specific for myelin basic protein. An unusual bias in antigen recognition. J. Exp. Med. 1985, 162, 2107-2124. [CrossRef] [PubMed]

24. Zhang, J.; Markovic-Plese, S.; Lacet, B.; Raus, J.; Weiner, H.L.; Hafler, D.A. Increased frequency of interleukin 2-responsive T cells specific for myelin basic protein and proteolipid protein in peripheral blood and cerebrospinal fluid of patients with multiple sclerosis. J. Exp. Med. 1994, 179, 973-984. [CrossRef] [PubMed]

25. Carbone, F.; De Rosa, V.; Carrieri, P.B.; Montella, S.; Bruzzese, D.; Porcellini, A.; Procaccini, C.; La Cava, A.; Matarese, G. Regulatory $\mathrm{T}$ cell proliferative potential is impaired in human autoimmune disease. Nat. Med. 2014, 20, 69-74. [CrossRef] [PubMed]

26. De Rosa, V.; Galgani, M.; Porcellini, A.; Colamatteo, A.; Santopaolo, M.; Zuchegna, C.; Romano, A.; De Simone, S.; Procaccini, C.; La Rocca, C.; et al. Glycolysis controls the induction of human regulatory T cells by modulating the expression of FOXP3 exon 2 splicing variants. Nat. Immunol. 2015, 16, 1174-1184. [CrossRef]

27. Batoulis, H.; Addicks, K.; Kuerten, S. Emerging concepts in autoimmune encephalomyelitis beyond the CD4/T(H)1 paradigm. Ann. Anat. 2010, 192, 179-193. [CrossRef]

28. Rayatpour, A. and Javan, M. Targeting the brain lesions using peptides: A review focused on the possibility of targeted drug delivery to multiple sclerosis lesions. Pharmacol. Res. 2021, 167, 105441. [CrossRef]

29. Badawi, A.H.; Siahaan, T.J. Immune modulating peptides for the treatment and suppression of multiple sclerosis. Clin. Immunol. 2012, 144, 127-138. [CrossRef] [PubMed]

30. Garber, K. Immunology: A tolerant approach. Nature 2014, 507, 418-420. [CrossRef] [PubMed]

31. Ponsford, M.; Mazza, G.; Coad, J.; Campbell, M.J.; Zajicek, J.; Wraith, D.C. Differential responses of CD45 ${ }^{\text {+ve }}$ T-cell subsets to MBP in multiple sclerosis. Clin. Exp. Immunol. 2001, 124, 315-322. [CrossRef] [PubMed]

32. Mazza, G.; Ponsford, M.; Lowrey, P.; Campbell, M.J.; Zajicek, J.; Wraith, D.C. Diversity and dynamics of the T-cell response to MBP in DR2 ${ }^{+v e}$ individuals. Clin. Exp. Immunol. 2002, 128, 538-547. [CrossRef]

33. Etzensperger, R.; McMahon, R.M.; Jones, E.Y.; Fugger, L. Dissection of the multiple sclerosis associated DR2 haplotype. J. Autoimmun. 2008, 31, 201-207. [CrossRef]

34. Ramagopalan, S.V.; Ebers, G.C. Multiple sclerosis: Major histocompatibility complexity and antigen presentation. Genome. Med. 2009, 1, 105. [CrossRef] [PubMed]

35. Streeter, H.B.; Rigden, R.; Martin, K.F.; Scolding, N.J.; Wraith, D.C. Preclinical development and first-in-human study of ATX-MS-1467 for immunotherapy of MS. Neurol. Neuroimmunol. Neuroinflamm. 2015, 2, 93. [CrossRef] [PubMed]

36. De Souza, A.L.S.; Rudin, S.; Chang, R.; Mitchell, K.; Crandall, T.; Huang, S.; Choi, J.K.; Okitsu, S.L.; Graham, D.L.; Tomkinson, B.; et al. ATX-MS-1467 Induces Long-Term Tolerance to Myelin Basic Protein in (DR2 x Ob1)F1 Mice by Induction of IL-10-Secreting iTregs. Neurol. Ther. 2018, 7, 103-128. [CrossRef] [PubMed]

37. Tselios, T.; Daliani, I.; Deraos, S.; Thymianou, S.; Matsoukas, E.; Troganis, A.; Gerothanassis, I.; Mouzaki, A.; Mavromoustakos, T.; Probert, L.; et al. Treatment of experimental allergic encephalomyelitis (EAE) by a rationally designed cyclic analogue of myelin basic protein (MBP) epitope 72-85. Bioorg. Med. Chem. Lett. 2000, 10, 2713-2717. [CrossRef] 
38. Tselios, T.; Apostolopoulos, V.; Daliani, I.; Deraos, S.; Grdadolnik, S.; Mavromoustakos, T.; Melachrinou, M.; Thymianou, S.; Probert, L.; Mouzaki, A.; et al. Antagonistic effects of human cyclic MBP (87-99) altered peptide ligands in experimental allergic encephalomyelitis and human T-cell proliferation. J. Med. Chem. 2002, 45, 275-283. [CrossRef] [PubMed]

39. Matsoukas, J.; Apostolopoulos, V.; Kalbacher, H.; Papini, A.M.; Tselios, T.; Chatzantoni, K.; Biagioli, T.; Lolli, F.; Deraos, S.; Papathanassopoulos, P.; et al. Design and synthesis of a novel potent myelin basic protein epitope 87-99 cyclic analogue: Enhanced stability and biological properties of mimics render them a potentially new class of immunomodulators. J. Med. Chem. 2005, 48 , 1470-1480. [CrossRef]

40. Deraos, G.; Rodi, M.; Kalbacher, H.; Chatzantoni, K.; Karagiannis, F.; Synodinos, L.; Plotas, P.; Papalois, A.; Dimisianos, N.; Papathanasopoulos, P.; et al. Properties of myelin altered peptide ligand cyclo (87-99)(Ala91,Ala96) MBP87-99 render it a promising drug lead for immunotherapy of multiple sclerosis. Eur. J. Med. Chem. 2015, 101, 13-23. [CrossRef]

41. Katsara, M.; Deraos, G.; Tselios, T.; Matsoukas, J.; Apostolopoulos, V. Design of novel cyclic altered peptide ligands of myelin basic protein MBP83-99 that modulate immune responses in SJL/J mice. J. Med. Chem. 2008, 51, 3971-3978. [CrossRef]

42. Katsara, M.; Deraos, G.; Tselios, T.; Matsoukas, M.T.; Friligou, I.; Matsoukas, J.; Apostolopoulos, V. Design and synthesis of a cyclic double mutant peptide (cyclo (87-99)[A91,A96] MBP87-99) induces altered responses in mice after conjugation to mannan: Implications in the immunotherapy of multiple sclerosis. J. Med. Chem. 2009, 52, 214-218. [CrossRef]

43. Gaur, A.; Boehme, S.A.; Chalmers, D.; Crowe, P.D.; Pahuja, A.; Ling, N.; Brocke, S.; Steinman, L.; Conlon, P.J. Amelioration of relapsing experimental autoimmune encephalomyelitis with altered myelin basic protein peptides involves different cellular mechanisms. J. Neuroimmunol. 1997, 74, 149-158. [CrossRef]

44. Karin, N.; Mitchell, D.J.; Brocke, S.; Ling, N.; Steinman, L. Reversal of experimental autoimmune encephalomyelitis by a soluble peptide variant of a myelin basic protein epitope: $\mathrm{T}$ cell receptor antagonism and reduction of interferon gamma and tumor necrosis factor alpha production. J. Exp. Med. 1994, 180, 2227-2237. [CrossRef]

45. Emmanouil, M.; Tseveleki, V.; Triantafyllakou, I.; Nteli, A.; Tselios, T.; Probert, L. A Cyclic Altered Peptide Analogue Based on Myelin Basic Protein 87-99 Provides Lasting Prophylactic and Therapeutic Protection Against Acute Experimental Autoimmune Encephalomyelitis. Molecules 2018, 23, 304. [CrossRef]

46. Mangan, P.R.; Harrington, L.E.; O'Quinn, D.B.; Helms, W.S.; Bullard, D.C.; Elson, C.O.; Hatton, R.D.; Wahl, S.M.; Schoeb, T.R.; Weaver, C.T. Transforming growth factor-beta induces development of the T(H)17 lineage. Nature 2006, 441, 231-234. [CrossRef] [PubMed]

47. Veldhoen, M.; Hocking, R.J.; Flavell, R.A.; Stockinger, B. Signals mediated by transforming growth factor-beta initiate autoimmune encephalomyelitis, but chronic inflammation is needed to sustain disease. Nat. Immunol. 2006, 7, 1151-1156. [CrossRef] [PubMed]

48. Bettelli, E.; Carrier, Y.; Gao, W.; Korn, T.; Strom, T.B.; Oukka, M.; Weiner, H.L.; Kuchroo, V.K. Reciprocal developmental pathways for the generation of pathogenic effector TH17 and regulatory T cells. Nature 2006, 441, 235-238. [CrossRef] [PubMed]

49. Chung, Y.; Chang, S.H.; Martinez, G.J.; Yang, X.O.; Nurieva, R.; Kang, H.S.; Ma, L.; Watowich, S.S.; Jetten, A.M.; Tian, Q.; et al. Critical regulation of early Th17 cell differentiation by interleukin-1 signaling. Immunity 2009, 30, 576-587. [CrossRef] [PubMed]

50. Goedkoop, A.Y.; Kraan, M.C.; Picavet, D.I.; de Rie, M.A.; Teunissen, M.B.; Bos, J.D.; Tak, P.P. Deactivation of endothelium and reduction in angiogenesis in psoriatic skin and synovium by low dose infliximab therapy in combination with stable methotrexate therapy: A prospective single-centre study. Arthritis Res. Ther. 2004, 6, 326-334. [CrossRef] [PubMed]

51. Canete, J.D.; Pablos, J.L.; Sanmarti, R.; Mallofre, C.; Marsal, S.; Maymo, J.; Gratacos, J.; Mezquita, J.; Mezquita, C.; Cid, M.C. Antiangiogenic effects of anti-tumor necrosis factor alpha therapy with infliximab in psoriatic arthritis. Arthritis Rheum. 2004, 50, 1636-1641. [CrossRef] [PubMed]

52. Kurohori, Y.; Sato, K.; Suzuki, S.; Kashiwazaki, S. Adhesion molecule expression on peripheral blood mononuclear cells in rheumatoid arthritis: Positive correlation between the proportion of L-selectin and disease activity. Clin. Rheumatol. 1995, 14, 335-341. [CrossRef] [PubMed]

53. Murugaiyan, G.; Mittal, A.; Weiner, H.L. Increased osteopontin expression in dendritic cells amplifies IL-17 production by CD4+ $\mathrm{T}$ cells in experimental autoimmune encephalomyelitis and in multiple sclerosis. J. Immunol. 2008, 181, 7480-7488. [CrossRef] [PubMed]

54. Steinman, L. Shifting therapeutic attention in MS to osteopontin, type 1 and type 2 IFN. Eur. J. Immunol. 2009, 39, 2358-2360. [CrossRef]

55. Han, M.H.; Hwang, S.I.; Roy, D.B.; Lundgren, D.H.; Price, J.V.; Ousman, S.S.; Fernald, G.H.; Gerlitz, B.; Robinson, W.H.; Baranzini, S.E.; et al. Proteomic analysis of active multiple sclerosis lesions reveals therapeutic targets. Nature 2008, 451, $1076-1081$. [CrossRef]

56. Teesalu, T.; Hinkkanen, A.E.; Vaheri, A. Coordinated induction of extracellular proteolysis systems during experimental autoimmune encephalomyelitis in mice. Am. J. Pathol. 2001, 159, 2227-2237. [CrossRef]

57. Du, F.; Garg, A.V.; Kosar, K.; Majumder, S.; Kugler, D.G.; Mir, G.H.; Maggio, M.; Henkel, M.; Lacy-Hulbert, A.; McGeachy, M.J. Inflammatory Th17 Cells Express Integrin alphavbeta3 for Pathogenic Function. Cell Rep. 2016, 16, 1339-1351. [CrossRef] [PubMed]

58. Comegna, D.; Zannetti, A.; Del Gatto, A.; de Paola, I.; Russo, L.; Di Gaetano, S.; Liguoro, A.; Capasso, D.; Saviano, M.; Zaccaro, L. Chemical Modification for Proteolytic Stabilization of the Selective alphavbeta3 Integrin RGDechi Peptide: In Vitro and in Vivo Activities on Malignant Melanoma Cells. J. Med. Chem. 2017, 60, 9874-9884. 
59. Bolzati, C.; Salvarese, N.; Carpanese, D.; Seraglia, R.; Melendez-Alafort, L.; Rosato, A.; Capasso, D.; Saviano, M.; Del Gatto, A.; Comegna, D.; et al. [(99m)Tc][Tc(N)PNP43]-Labeled RGD Peptides As New Probes for a Selective Detection of alphavbeta3 Integrin: Synthesis, Structure-Activity and Pharmacokinetic Studies. J. Med. Chem. 2018, 61, 9596-9610. [CrossRef]

60. Komegae, E.N.; Souza, T.A.; Grund, L.Z.; Lima, C.; Lopes-Ferreira, M. Multiple functional therapeutic effects of TnP: A small stable synthetic peptide derived from fish venom in a mouse model of multiple sclerosis. PLoS ONE 2017, 12, 171796. [CrossRef]

61. Baxter, A.G. The origin and application of experimental autoimmune encephalomyelitis. Nat. Rev. Immunol. 2007, 7, 904-912. [CrossRef] [PubMed]

62. Hiremath, M.M.; Saito, Y.; Knapp, G.W.; Ting, J.P.; Suzuki, K.; Matsushima, G.K. Microglial/macrophage accumulation during cuprizone-induced demyelination in C57BL/ 6 mice. J. Neuroimmunol. 1998, 92, 38-49. [CrossRef]

63. Praet, J.; Guglielmetti, C.; Berneman, Z.; Van der Linden, A.; Ponsaerts, P. Cellular and molecular neuropathology of the cuprizone mouse model: Clinical relevance for multiple sclerosis. Neurosci. Biobehav. Rev. 2014, 47, 485-505. [CrossRef]

64. Craik, D.J. Plant cyclotides: Circular, knotted peptide toxins. Toxicon 2001, 39, 1809-1813. [CrossRef]

65. Grundemann, C.; Thell, K.; Lengen, K.; Garcia-Kaufer, M.; Huang, Y.H.; Huber, R.; Craik, D.J.; Schabbauer, G.; Gruber, C.W. Cyclotides Suppress Human T-Lymphocyte Proliferation by an Interleukin 2-Dependent Mechanism. PLoS ONE 2013, 8, 68016. [CrossRef]

66. Thell, K.; Hellinger, R.; Sahin, E.; Michenthaler, P.; Gold-Binder, M.; Haider, T.; Kuttke, M.; Liutkeviciute, Z.; Goransson, U.; Grundemann, C.; et al. Oral activity of a nature-derived cyclic peptide for the treatment of multiple sclerosis. Proc. Natl. Acad. Sci. USA 2016, 113, 3960-3965. [CrossRef] [PubMed]

67. Yue, Y.; Stone, S.; Lin, W. Role of nuclear factor kappaB in multiple sclerosis and experimental autoimmune encephalomyelitis. Neural. Regen. Res. 2018, 13, 1507-1515.

68. Lunin, S.M.; Khrenov, M.O.; Glushkova, O.V.; Parfenyuk, S.B.; Novoselova, T.V.; Novoselova, E.G. Immune response in the relapsing-remitting experimental autoimmune encephalomyelitis in mice: The role of the NF-kappaB signaling pathway. Cell Immunol. 2019, 336, 20-27. [CrossRef]

69. Lunin, S.M.; Novoselova, E.G. Thymus hormones as prospective anti-inflammatory agents. Expert. Opin. Ther. Targets 2010, 14, 775-786. [CrossRef] [PubMed]

70. Lunin, S.M.; Khrenov, M.O.; Novoselova, T.V.; Parfenyuk, S.B.; Novoselova, E.G. Thymulin, a thymic peptide, prevents the overproduction of pro-inflammatory cytokines and heat shock protein $\mathrm{Hsp70}$ in inflammation-bearing mice. Immunol. Investig. 2008, 37, 858-870. [CrossRef] [PubMed]

71. Novoselova, E.G.; Khrenov, M.O.; Glushkova, O.V.; Lunin, S.M.; Parfenyuk, S.B.; Novoselova, T.V.; Fesenko, E.E. Antiinflammatory effects of IKK inhibitor XII, thymulin, and fat-soluble antioxidants in LPS-treated mice. Mediat. Inflamm. 2014, 2014, 724838. [CrossRef] [PubMed]

72. Safieh-Garabedian, B.; Nomikos, M.; Saade, N. Targeting inflammatory components in neuropathic pain: The analgesic effect of thymulin related peptide. Neurosci. Lett. 2019, 702, 61-65. [CrossRef] [PubMed]

73. Lunin, S.M.; Glushkova, O.V.; Khrenov, M.O.; Novoselova, T.V.; Parfenyuk, S.B.; Fesenko, E.E.; Novoselova, E.G. Thymic peptides restrain the inflammatory response in mice with experimental autoimmune encephalomyelitis. Immunobiology 2013, 218, $402-407$. [CrossRef] [PubMed]

74. Lunin, S.M.; Khrenov, M.O.; Novoselova, T.V.; Parfenyuk, S.B.; Glushkova, O.V.; Fesenko, E.E.; Novoselova, E.G. Modulation of inflammatory response in mice with severe autoimmune disease by thymic peptide thymulin and an inhibitor of NF-kappaB signaling. Int. Immunopharmacol. 2015, 25, 260-266. [CrossRef]

75. Lunin, S.M.; Khrenov, M.O.; Glushkova, O.V.; Parfenyuk, S.B.; Novoselova, T.V.; Novoselova, E.G. Protective Effect of PBCA Nanoparticles Loaded with Thymulin Against the Relapsing-Remitting Form of Experimental Autoimmune Encephalomyelitis in Mice. Int. J. Mol. Sci. 2019, 20, 5374. [CrossRef]

76. Novoselova, E.G.; Lunin, S.M.; Glushkova, O.V.; Khrenov, M.O.; Parfenyuk, S.B.; Zakharova, N.M.; Fesenko, E.E. Thymulin, free or bound to PBCA nanoparticles, protects mice against chronic septic inflammation. PLoS ONE 2018, 13, 197601. [CrossRef] [PubMed]

77. Stangel, M.; Kuhlmann, T.; Matthews, P.M.; Kilpatrick, T.J. Achievements and obstacles of remyelinating therapies in multiple sclerosis. Nat. Rev. Neurol. 2017, 13, 742-754. [CrossRef]

78. Fletcher, J.L.; Wood, R.J.; Nguyen, J.; Norman, E.M.L.; Jun, C.M.K.; Prawdiuk, A.R.; Biemond, M.; Nguyen, H.T.H.; Northfield, S.E.; Hughes, R.A.; et al. Targeting TrkB with a Brain-Derived Neurotrophic Factor Mimetic Promotes Myelin Repair in the Brain. J. Neurosci. 2018, 38, 7088-7099. [CrossRef]

79. Minagar, A.; Alexander, J.S. Blood-brain barrier disruption in multiple sclerosis. Mult. Scler. 2003, 9, 540-549. [CrossRef]

80. Adams, R.A.; Bauer, J.; Flick, M.J.; Sikorski, S.L.; Nuriel, T.; Lassmann, H.; Degen, J.L.; Akassoglou, K. The fibrin-derived gamma377-395 peptide inhibits microglia activation and suppresses relapsing paralysis in central nervous system autoimmune disease. J. Exp. Med. 2007, 204, 571-582. [CrossRef]

81. Yuan, R.; Maeda, Y.; Li, W.; Lu, W.; Cook, S.; Dowling, P. Erythropoietin: A potent inducer of peripheral immuno/inflammatory modulation in autoimmune EAE. PLoS ONE 2008, 3, 1924. [CrossRef] [PubMed]

82. Dicato, M. Venous thromboembolic events and erythropoiesis-stimulating agents: An update. Oncologist 2008, 13, 11-15. [CrossRef] [PubMed] 
83. Ehrenreich, H.; Weissenborn, K.; Prange, H.; Schneider, D.; Weimar, C.; Wartenberg, K.; Schellinger, P.D.; Bohn, M.; Becker, H.; Wegrzyn, M.; et al. Recombinant human erythropoietin in the treatment of acute ischemic stroke. Stroke 2009, 40, 647-656. [CrossRef] [PubMed]

84. Corwin, H.L.; Gettinger, A.; Fabian, T.C.; May, A.; Pearl, R.G.; Heard, S.; An, R.; Bowers, P.J.; Burton, P.; Klausner, M.A.; et al. Efficacy and safety of epoetin alfa in critically ill patients. N. Engl. J. Med. 2007, 357, 965-976. [CrossRef]

85. Yuan, R.; Wang, B.; Lu, W.; Maeda, Y.; Dowling, P. A Distinct Region in Erythropoietin that Induces Immuno/Inflammatory Modulation and Tissue Protection. Neurotherapeutics 2015, 12, 850-861. [CrossRef]

86. Wang, B.; Kang, M.; Marchese, M.; Rodriguez, E.; Lu, W.; Li, X.; Maeda, Y.; Dowling, P. Beneficial Effect of Erythropoietin Short Peptide on Acute Traumatic Brain Injury. Neurotherapeutics 2016, 13, 418-427. [CrossRef] [PubMed]

87. Li, W.; Maeda, Y.; Yuan, R.R.; Elkabes, S.; Cook, S.; Dowling, P. Beneficial effect of erythropoietin on experimental allergic encephalomyelitis. Ann. Neurol. 2004, 56, 767-777. [CrossRef]

88. Liddelow, S.A.; Guttenplan, K.A.; Clarke, L.E.; Bennett, F.C.; Bohlen, C.J.; Schirmer, L.; Bennett, M.L.; Munch, A.E.; Chung, W.S.; Peterson, T.C.; et al. Neurotoxic reactive astrocytes are induced by activated microglia. Nature 2017, 541, 481-487. [CrossRef]

89. Gaindh, D.; Choi, Y.B.; Marchese, M.; Dowling, P.; Cook, S.; Blumberg, B.; Park, J.H.; Lu, W. Prolonged Beneficial Effect of Brief Erythropoietin Peptide JM4 Therapy on Chronic Relapsing EAE. Neurotherapeutics 2020, 18, 401-411. [CrossRef]

90. Sorensen, P.S.; Sellebjerg, F. Pulsed immune reconstitution therapy in multiple sclerosis. Ther. Adv. Neurol. Disord. 2019, 12. [CrossRef] [PubMed] 